\title{
Federal Equality in Multinational Bosnia and Herzegovina
}

\author{
Dejan Vanjek
}

This chapter re-examines Bosnia and Herzegovina $(\mathrm{BiH})$ as a multinational federation and focuses on the self-rule/shared-rule principles as tools for assessment of the equality of the three constituent peoples - Bosniaks, Serbs, Croats - and 'Others'. The category of 'constituency' in the BiH Constitution implies full normative-statutory equality of the three constituent peoples as state-creating subjects. Therefore, by examining the level of symmetric distribution of the two federal principles amongst them, across key institutionalpolitical structures, hotspots of their inequality can be unravelled. The relevant finding is that, for different reasons addressed in this chapter, there are factual institutional inequalities and asymmetries in place that depart from the normative constitutional equality. This chapter's main claim is that these factual institutional inequalities and asymmetries must be dealt with in order to achieve the constitutionally required symmetric positioning of the constituent peoples on the level of the overall political system and its executive and legislative bodies. ${ }^{1}$

In an introductory theoretical section, we will further elaborate on the selfrule and shared-rule principles, their significance, mutual interaction and general relevance for maintaining the equality of the constituent political entities in multinational federal political systems. The second section consists of a disclosure of key constitutional and structural hallmarks of $\mathrm{BiH}$ as a multinational federation, with and beyond standard structural and formal descriptors. The focus will be set on the fundamental constitutional values, i.e. the 'hermeneutics' by which these values can be read and projected into the political

1 Institutions designed for collective representation of the constituent peoples, namely the House of Peoples, as an upper chamber primarily designed to account for the democratic political will of the constituent peoples, and tripartite Presidency composed of three members - Croat, Serb and Bosniak. 
system. In the third section, after having established the normative criteria for the relational measurement of the equality of the three constituent peoples, correlative to the $\mathrm{BiH}$ constitutional and legal-political setting, the chapter further overviews its institutional, legislative-political system. Thus, it inspects and discloses the key structural, institutional and representative aspects of (in)equality, filtered through the self-rule/shared-rule principles and their (a)symmetric distribution amongst the constituents. Such a path allows us to identify and unveil the case of institutional-political (in)equality in BiH's multinational federation in terms of the relative or full deprivation of, discrimination in, or limitations of access to political participation in BiH's political system. We will focus on the executive and legislative institutions on the various levels of governance in $\mathrm{BiH}$ as well as on the electoral provisions, which are the key prerequisite of a just and fair democratic representation. The electoral provisions, along with the consociation contrivances, are accentuated as a prerequisite to a thorough equalisation of the political position of the three constituent peoples.

Finally, as the BiH Constitution operates both with the constituent peoples and the category of 'Others', namely minorities and citizens who do not fall in the 'constituents' category, one must refer to individual equality adjudicated by several subsequent rulings of the European Court for Human Rights against $\mathrm{BiH} .{ }^{2}$ The rulings are then juxtaposed with the traditional provision of the $\mathrm{BiH}$ constitutional norm of 'constituency', which is primarily in place to safeguard communal political rights of the three constituent peoples, their mutual equality and symmetric statutory positioning. The intention is to indicate directions in which the equilibrium between individual and communal rights can be pursued in line with all the specificities and given value-normative contents of the $\mathrm{BiH}$ Constitution. The interest of such an approach is to broaden the lens for further consideration and understanding of the two-dimensional problem of (in)equalities in $\mathrm{BiH}$.

2 European Court of Human Rights, Sejdić-Finci v. Bosnia and Herzegovina (application nos. 27996/o6 and 34836/o6), Strasbourg, Judgment of 22 December 20o9; European Court of Human Rights, Pilav v. Bosnia and Herzegovina (application no. 41939/o7), Strasbourg, judgment of 9 June 2016; European Court of Human Rights, Zornic v. Bosnia and Herzegovina (Application no. 3681/o6), Strasbourg, Judgment of 15 July 2014; European Court of Human Rights, Slaku v. Bosnia and Herzegovina (Application no. 56666/12), Strasbourg, Judgment of 26 May 2016. Closer analysis of some of these cases is provided in the last section of the chapter. On this topic also Equality and Inequality in Bosnia and Herzegovina by Soeren Keil (chapter 12). 


\subsection{Shared-Rule and Self-Rule as Key Criteria of Federal Equality}

Multinational federations, unlike nation-states and national federations, connect the liberal conception of justice not only to individual civic rights, but also to group rights. ${ }^{3}$ On the value-based level they combine both liberal and communitarian principles ${ }^{4}$ which are then further fine-tuned and balanced across the system of governance. In fact, the entire conception of multinational federalism and its contrivances are bound to assure equality, harmonise diverse identities and create unity by regulating and balancing needs and particularities of inner federal constituencies. Whereas nation-states are willing and often prone to sacrifice their diversity to force unity, multinational federations do not know or practice such a trade-off. However, this entails the need for a much higher level of pacifism, voluntarism, ${ }^{5}$ and, foremost, generalised trust in the power of political deliberation and rational action. Namely, it requires a specific political culture based on 'win-win' values of compromise and consensus, instead of the 'winner takes all' approach, which is typical for the classic majoritarian political reasoning.

Undoubtedly, in multinational constitutional systems designed to unite and accommodate diverse identities, the visibility and relevance of group equality increases. However, its implementation and assessment can be very challenging, especially because it can be relativised or manipulated via different political arguments or burdened by imperfections of the constitutional text, by a lack of consensual tradition and political culture, disparities of the real social, economic and political power of the constituent entities, etc. For these reasons, it is important to use universal criteria for the assessment of equality in multinational federations, composed of at least two or more identity groups with constitutionally equal normative status and entitlements. ${ }^{6}$

If federalism is the broadest basic form that allows for constitutional entrenchment and accommodation of diversity by protecting both the equality of the individuals and the constituent entities, it is legitimate to consider its two core principles, the backbones of comprehensive and systemic measurement

3 Soeren Keil,MultinationalFederalisminBosniaandHerzegovina(London,NewYork:Routledge, 2016), 45 .

4 Tomas Fleiner and Lidija Basta, Constitutional Democracy in a Multicultural and Globalized World (Berlin, Heidelberg: Springer-Verlag, 2009), 161.

5 Amongst others particularly emphasised in Nancy Bermeo, "The Import of Institutions," Journal of Democracy 13, no. 2 (April 2002): 96-110.

6 Bosnia and Herzegovina is clearly the example of such a multinational federation. 
of federal equality. Self-rule and shared-rule can be deeply integrated into federal theory and, from there, into different policy and governance areas of federalism. ${ }^{7}$ It is difficult to imagine any federal or even quasi-federal system that would not embed these principles naturally, with variance in methods, depths, and extents of their application. These are systemic categories present within all segments of the federal system and as such they predetermine the equality relations therein. Thus, John McGarry wrote that 'federal political systems is a descriptive catchall term for all political organizations that combine what Daniel Elazar called shared rule and self-rule'. ${ }^{8}$ Ronald Watts acknowledged that federalism 'refers to the advocacy of multi-tiered government combining elements of shared-rule and regional self-rule. ${ }^{9}$ However, the most comprehensive definition of federalism, which accounted for both its vertical and horizontal systemic dimensions and equality as its key inherent ingredient, expressed the idea of federal equality in the following way:

In the federal model, polities are established by equals who come together do so by design in such a way to protect the respective integrities of the founders even while they join together to form a new body politic. Rule is the rule of equals by equals and is designed to maintain that basic principle. $^{10}$

Elazar's definition reflects a deep understanding of federalism as a system which clearly incorporates a group dimension and equally involves both 'shared governance rule' and 'self-governance rule', whereby the former expands to all areas relevant for peace and stability, and the latter has a clear purpose to 'allow all parties to preserve their respective integrities'.1 Equally important

This was strongly recognised by Preston King who noticed that 'Federalism is a normative political philosophy that recommends the use of federal principles i.e. combining joint action and self-government'; Preston King, Federalism and Federation (London: Crom Helm, 1982). John McGarry and Brendan O'Leary, "Federation as a Method of Ethnic Conflict Regulation," forumfed.org (2004): 1, http://www.forumfed.org/libdocs/Misc/o4o1-intMcGarry-OLeary.pdf.

9 Ronald Watts, Comparing Federal Systems (Montreal, Kingston: McGill-Queen's University Press, 2008), 8.

10 Daniel J. Elazar, Exploring Federalism (Tuscaloosa: University of Alabama Press, 1987), 10. Elazar's definition particularly resonates with BiH's constitutional framework and its fundamental ingredient, the constituent people Bosniaks, Serbs and Croats, as legitimate primary agents of the respective federal constitutional order. As such, they are entitled to dispose with equal/symmetric shared and self-rule capacities in both common and autonomous spheres.

Ibid. 
and necessary to sustain a federal balance of equality, they are not concurrent and do not meet identical goals and needs. However, they do serve the same purpose, which is to assure the stability of a federal order by harmonising internal positions and relations of constituent subjects. Balance is maintained by carefully tailoring, dosing and balancing the shared-rule/self-rule binomial across the whole political system. Furthermore, Elazar's definition positions self- and shared-rule both in their horizontal societal form and transfers them to a constitutional wording and vertical framework. As such, they are further formalised through adequate structuring of the federation and application of correspondent organisational principles, regulatory frameworks, and complementary institutions. In other words, only in multinational federations can self-rule/shared-rule be read as systemic principles that permeate all layers and spheres of the federal political system, which is the reason why they can be identified and used as reliable criteria for a systemic assessment of the equality of relations. As such, they must be accounted in the design of multinational federations, but can also be used for their in-depth examination, including major equality relations.

\subsection{Federal Balance and (A)Symmetric Application of Self- and Shared-Rule}

For a thorough reading of Elazar's all-encompassing definition, it is also necessary to accentuate the organic connection between self-rule and shared-rule contained therein. Namely, the integrity of the constituent entities is not only protected by self-rule, but also through shared-rule. If we take the integrity primarily shielded by self-rule as the form of political subjectivity and a precondition for all participatory action within the political system, then integrity as subjectivity must be respected and ensured in the shared-rule segment as well. For example, if a dominant group attempts unilaterally to alter the electoral procedures and processes or to undermine consociation rules leading to a situation where the integrity of a minority nation is gravely affected, such actions would not only impair the rights of said minority nation, but also the balance of equality across the entire system of governance, therefore destabilising it. From the opposite side, shared-rule shields self-rule by preventing unilateral decisions at the centre, which could undermine the position of weaker federation members. Hence, shared-rule also provides space to build in the will of all the constituencies into overall decision-making. That political will is then an expression and extension of their right to autonomy and the constituent status, which implies that disruption of shared-rule leads to a violation of the political will and the undermining of constitutional rights of the constituents. 
Therefore, self-rule and shared-rule are two interdependent and complementary principles, and neither of them can work without the other. Namely, self-rule empowers shared-rule, whereas shared-rule, in return, guarantees the protection of the autonomy expressed through the self-rule competencies of the constituent members in a multinational federation. Such an intricate balance of the two federal principles, based on their organic interdependence, enables normative and factual equality of the constituent entities regulated through their continuous observance, management, and application. In multinational federations, both principles converge more than elsewhere, as the relevance and role of the shared-rule increases. ${ }^{12}$

A balanced application of the two federal principles on the level of the overall socio-political system helps to consolidate structural equality. ${ }^{13}$ That balance is based on the ratio of dispositions of all self- and shared-rule provisions across the federal system, its institutions, and regulatory framework, against each one of the constituent/constitutional subjects. ${ }^{14}$ In other words, the only relation that matters more than the ratio of overall application of the two principles throughout the legal-political system is their equal, i.e. symmetric, allocation to all the constituents. In that sense, symmetric scale and volume of autonomy as well as shared access and influence on co-decision-making by all the constituencies represents the backbone of multinational federal equality and determines its objective quality.

Federal balance in the sense of symmetric disposition of the self-rule and shared-rule powers amongst the constituents plays an important role in the stability and sustainability of multinational federations. Symmetric structural distribution of federal principles allows both vertical and horizontal finetuning of the system, predominantly through a combination of classic federal and consociate organisational, regulative, and governance techniques. ${ }^{15}$ However, their structural symmetric application does not always lead to equality. It is more often the case that asymmetry is used to empower national minorities in multinational federations and, in that way, to converge systems closer to general standards of equality. Such a form of equality then relates specifically to social and political realities where the liberal notion of civic

12 Ronald Watts, "Multinational Federations in Comparative Perspective," in Multinational Federations, eds. Michael Burgess and John Pinder (London: Routledge, 2007), 232.

13 Michael Ignatief, The Right Revolution (Toronto: House of Anansi Press Ltd, 2001), 84.

14 Watts, "Multinational Federations," 231-232.

15 Vertical in the sense of necessary alignment of the institutional and legal-political system with the constitutional norms and principles, and horizontal in terms of harmonisation of intergroup relations. 
equality must be expanded with the recognition of the right to be different. ${ }^{16}$ Multinational federations tend to recognise such realities by accommodating the constituent and constitutional status of different identity groups and nationalities, and try to reconcile and harmonise them. ${ }^{17}$ To that purpose, both symmetry and asymmetry can be used to bolster equality in multinational federations, dependent on the specifics of the social, political, and constitutional setting. ${ }^{18}$ Moreover, asymmetry is better seen as an efficient equaliser than as a means to achieve full-fledged equality. ${ }^{19}$ As such it is often considered and used to empower minority groups beyond their actual demographic potential in the face of actual power of other dominant groups. However, asymmetric solutions are more prone to protect differences than to establish intergroup equality. ${ }^{20}$ For that reason, they can never create a system of full group equality, but rather serve as an efficient 'equalisation' tool applied to bust self-rule capacities of the respective minority groups and increase the general level of their relative equality. ${ }^{21}$

Moreover, asymmetric arrangements are usually negotiated between the central government and a nation that seeks more self-rule to better protect its identity and economic self-sufficiency in the specific territory. This kind of relation requires daily compromise, but not consensus, as it is up to the centre in the end, namely its political establishment and institutions, to decide how to manage the claims of the claimant. On the other side, symmetry is a key precondition for equality in multinational federations composed of at least two constituent entities that share an identical constitutional (constituent) status and where equality of the constituent entities is implicit to the constitutional

16 Thomas Fleiner and Lidija Basta Fleiner, Constitutional Democracy in a Multicultural and Globalised World (Berlin, Heidelberg: Springer - Verlag, 2009), 573.

17 Brendan O'Leary, "Debating Consociational Politics: Normative and Explanatory Arguments," in From Power Sharing to Democracy: Post-Conflict Institutions in Ethnically Divided Societies, ed. Sid Noel (Montreal, Kingston, London, Ithaca: McGill-Queen's University Press, 2005), 272.

18 Some authors prize asymmetry over symmetry as an intrinsic federal value, e.g. Alain Gagnon, "The Moral Foundation of Asymmetrical Federalism: A Normative Exploration of the Case of Quebec and Canada," in Multinational Democracies, eds. Alain Gagnon and James Tully (Cambridge: Cambridge University Press, 2001), 319-327.

19 Michael Burgess, Comparative Federalism: Theory and Practice (London, New York: Routledge, 2006), 221.

20 Ibid.

21 The reasoning outlined here is inspired by the experience of $\mathrm{BiH}$ multinational federalism and its social, political and constitutional conditions. As such, it does not represent a general critique of asymmetry, but rather one of novel perspectives and understandings resulting from the case of $\mathrm{BiH}$. 
wording. Such are polities in which constituent entities are, in fact, statecreating subjects. ${ }^{22}$ Their constitutional equality can only be expressed if symmetrically transferred to the key legislative and governance institutions, as well as the correspondent political practices within the self-rule/shared-rule segments. The basis of such polity then is a composite political community in which the central government is not an independent governance entity but shared by the constituents. For this reason, within them there cannot be a selfsufficient, sovereign centre independent from the will of its constituencies. In other words, without participation of all the constituencies there cannot be a centre in the sense of a central government functioning independently from its constituencies. Such a multinational 'centre' is closer to a 'shared order of governance', which operates based on thorough symmetric application of the will of the constituent entities through shared-rule.

Therefore, unlike multinational federations with constitutional asymmetries, dynamics in multinational federations with embedded constitutional symmetry must also be regulated horizontally, in between different yet statutorily equal constituent entities (groups, units, peoples etc.). Though such relations can be read as confederate, they also tell us about how different power-sharing concepts (confederal, federal, consociate, etc.) can meet and intersect within the same constitutional-legal political system. From here, we delve into a closer examination of Bosnia and Herzegovina's constitutional system that incorporates both symmetric and asymmetric elements.

\section{Reflections on the Nature of the BiH Multinational Federation}

The foundations of the current constitutional order in Bosnia and Herzegovina are based on two peace agreements and the constitutions derived from those agreements. The first peace agreement is the Washington Agreement, signed on 18 March 1994. It ended an intense year-long Croat-Bosniak conflict in Bosnia-Herzegovina, and further set military and political preconditions for ending hostilities in the whole country. The subsequent signing of the General Framework Agreement for Peace in Bosnia and Herzegovina, better known as the Dayton Peace Agreement (DPA), established the current dyadic two-entity federal structure (the Republika Srpska (RS) and the Federation of Bosnia and Herzegovina $(\mathrm{FBiH})) .{ }^{23}$ As such, Bosnia and Herzegovina is a post-conflict

\footnotetext{
22 Constituent peoples as constitutional/state-creating units in Bosnia and Herzegovina.

23 The war and said peace treaties were predeceased by a referendum which took place on 29 February and 1 March 1992, based on which BiH was declared an independent
} 
society that requires incentives for inter-ethnic cooperation and strong guarantees that its political system can safeguard equal constitutional positions of the three constituent peoples (Serbs, Croats, and Bosniaks) as well as other citizens, including different minority groups and individuals.

In principle, the DPA's constitutional order of Bosnia and Herzegovina has already been designated by eminent scholars as a multinational federation, ${ }^{24}$ based on its key formal and structural criteria. ${ }^{25}$ Such a specific account was provided by Michael Burgess who defined Bosnia and Herzegovina as a dyadic, multinational federation: one state, two entities and three ethnonational communities. ${ }^{26}$ This succinct formula informs the key elements of the BiH Constitution and its political organisation. However, it does not say anything about their individual, normative weight, namely, how they define the nature of the $\mathrm{BiH}$ constitutional order and how corporate (constituent peoples) and territorial (entities) components mutually correlate: which of them take precedence over the other and for what normative reasons? These questions become even more relevant if we look at the following diagnostic assessment:

state, followed by the abstinence of the Serb constituent people and the rejection of its results by their political leaders. International recognition soon followed, but the relations within the state were becoming increasingly tense and very soon led to a war, which lasted from 1992 to 1995 and resulted in a massive loss of lives and destruction. Diplomatic and military pressure by the international community under the leadership of the USA, which brokered the Dayton Peace Agreement signed on 14 December 1995 in Paris, ended the war. The Agreement verified internationally recognised borders, sovereignty, territorial integrity and introduced a new territorial organisation of the country.

24 Although it must be said that there are also assessments of $\mathrm{BiH}$ as a confederal state. In that sense see Sujit Choudhry, "Bridging Comparative Politics and Comparative Constitutional Law: Constitutional Design in Divided Societies," in Constitutional Design for Divided Societies: Integration or Accommodation?, ed. Sujit Choudhry (Oxford: Oxford University Press, 2008), 12.

25 For such qualification with an accompanying set of supportive arguments it suffices to single out Soeren Keil, "Federalism as a Tool of Conflict-Resolution: The Case of Bosnia and Herzegovina," L'Europe en formation, no. 1 (2012): 205-218. Another similar definition of $\mathrm{BiH}$ as a multinational federation was provided by Michael Burgess, "Territorial and Non-Territorial Identities: Multinational Federalism in Multinational Federation," Paper prepared for the conference 'Multinational Federalism in Perspective: A Viable Model?, Université du Quebec à Montreal (UQAM), Montreal, Quebec, Canada, 25-27 September 2009 (Canterbury: Centre For Federal Studies, Rutherford College, University of Kent, 2009), https://www.academia.edu/1471289o/Territorial_and_Non-Territorial_Identities_ Multinational_Federalism_in_Multinational_Federation. 
The centripetal forces for unity and integration are weaker than the centrifugal interests represented by the existing entities that see very few incentives to support the state. Consequently, $\mathrm{BiH}$ is for the purposes of our survey a remarkable case study of a potential multinational federation without multinational federalism. In short, it exhibits federation without federalism. ${ }^{27}$

This argument complements the thesis that $\mathrm{BiH}$, as a federation, is missing a nexus to its fundamental constitutional values and hence lacks supportive federal political culture, which would energise its federalism and internal federalisation process. The role and importance of multinational federalism as the internal animating force of a multinational federation has been widely acknowledged as such. ${ }^{28}$ Drawing further on the thought of Preston King that there cannot be a federation without federalism as its inner mover, Michael Burgess developed the idea of a federalist spirit and enumerated federal values. $^{29}$ Since federal culture and its values are inseparable from federalism, the (in)existence of such a culture strongly influences the level of respect and harmonised understanding of fundamental constitutional principles amongst relevant political, institutional, social, and scientific authorities that could further shape all subsequent (mis)perceptions of $\mathrm{BiH}$ as a multinational federation. ${ }^{30}$ Thus, for the correct reading of its constitutional values, the answer to the question on the nature of BiH's constitutional order must be expanded via pathways of 'constitutional hermeneutics' to ascertain which principles constitute $\mathrm{BiH}$ as a multinational federation.

The DPA Constitution of Bosnia and Herzegovina explicitly entitles the constituent peoples Bosniaks, Serbs and Croats as titulars of state sovereignty. ${ }^{31}$

\footnotetext{
27 Burgess, "Territorial and Non-Territorial Identities," 24.

28 Burgess, Comparative Federalism, 2-3.

29 Michael Burgess, In Search of the Federal Spirit: New Theoretical and Empirical Perspectives in Comparative Federalism, (Oxford: Oxford University Press, 2012).

30 Keil, Multinational Federalism, 144-147.

31 A notion self-evident from the constitution but also undisputed and confirmed by scholars and professional authorities such as Sheri P. Rosenberg, who argued that 'constituent peoples' essentially amounts to 'state creating' peoples. See Sheri P. Rosenberg, "Promoting Equality after Genocide," Tulane Journal of International and Comparative Law (2007): 329 .
} 
Specifically, the Preamble of the Constitution provides that 'Bosniaks, Croats, and Serbs, as constituent peoples (in community with others), and citizens of Bosnia and Herzegovina hereby ascertain Constitution of Bosnia and Herzegovina.' This is a fundamental constitutional premise that defines the constituent peoples and 'Others' (national minorities' et al.) as bearers of BiH's sovereignty. The top hierarchical constitutional position of the 'constituency' was also reaffirmed in the decision of the BiH Constitutional Court ref. U-5/ 98 delivered in the year 2000, where it was elaborated as an overarching constitutional category superimposed to all constitutional principles, laws, and regulations. ${ }^{32}$ Moreover, even in all earlier pre-Dayton constitutions from the socialist period when $\mathrm{BiH}$ was part of the larger Yugoslav pseudo-federation, Serbs, Croats, and Bosniaks were entrenched as primary constitutional subjects and bearers of sovereignty upon which $\mathrm{BiH}$ statehood was founded. This fact informs us that $\mathrm{BiH}$ was a multinational country even before the DPA Constitution in 1995, by which its federal-like organisation and structure were introduced and formalised.

While some critiques question the legitimacy of the $\mathrm{BiH}$ federation as artificial and imposed, ${ }^{33}$ the fact remains that $\mathrm{BiH}$ was a quasi-federal society even before it acquired visible institutional, structural, and organisational hallmarks of federation. If these facts are neglected, logical outcomes can hardly be other than misleading. For this reason, it is necessary to go beyond basic formal structural criteria and resort to constitutional hermeneutics and phenomenology in search of 'ground zero' of a BiH constitutionalism. After doing so, it will be legitimate to conclude that the dyadic organisation of the country cannot be taken as a central argument in support of BiH's multinational character. Rather, the hierarchy of principles outlined in the Constitution imply that the 'constituent' status of Serbs, Croats, and Bosniaks is superior to the administrative-political organisation and as such it precedes organisational principles of the State. ${ }^{34}$ Namely, the case is that the substance and nature of $\mathrm{BiH}$ as a multinational federation is not of territorial, but of corporativecommunitarian character. This is crucial for a thorough understanding of the $\mathrm{BiH}$ multinational federation.

32 Constitutional Court of Bosnia and Herzegovina, Judgment no. U-5/98, 'On Constituency', 26, Sarajevo, 30 January 20oo; available at http://www.ccbh.ba/odluke/.

33 The legitimacy of $\mathrm{BiH}$ is in fact questioned because its Federalism was considered as imposed by an external force and could not develop from within. See Burgess, In Search of the Federal Spirit, 275 .

34 As clearly outlined in the CC BiH judgment 'On Constituency' no. U-5/98, 'On Constituency', 26, Sarajevo, 30 January 2000; available at http://www.ccbh.ba/odluke/. 
It follows that the key elements of BiH's constitutional order are in fact the constituent peoples, which are of utmost importance for a further accurate and consistent approach to the $\mathrm{BiH}$ constitutionalism. Clearly, neither any abstract citizen nor a non-existent singular political people (i.e. demos) of Bosnia and Herzegovina, or its current two entities ( $\mathrm{FBiH}$ and $\mathrm{Rs}$ ) constitute BiH. On the contrary, it is evident that $\mathrm{BiH}$ and its Constitution were ascertained by the constituent peoples Serbs, Bosniaks, and Croats as the three distinctive and sovereign 'demoi'. As state-creating subjects, they have agreed through their representatives in Dayton to uphold the dyadic organisation of the country, but not at the expense of their constituent status and their equality. In fact, they have agreed to the existent dyadic-asymmetric organisation in good faith, with reasonable expectations that such organisation would safeguard their particular and shared interests.

As such, the constituent status ${ }^{35}$ assigned to each of the three peoples in the DPA Constitution produces far-reaching implications beyond formal constitutional analysis and framing. Namely, it implies belonging to a larger whole, made up of equal constituent members, whose subjectivity is directly conditioned and determined by their belonging to a larger political community beyond which their subjectivity is unimaginable and undeliverable. ${ }^{36}$ Is the 'constituency' specific to Bosnia and Herzegovina or a unique practical constitutional stronghold unknown to political sciences theory? It is neither, because even in countries where there is a singular political community or nation (demos), the constituent status is immanent to the core group, i.e. populous or 'Staatsvolk'. For that reason, there is no need for its explicit emphasis. However, in a compound state comprised of more than one people and of a plurality of political identities with explicit and unequivocal constitutional expression, the 'constituency' accentuates the multinational character of the country, as well as its related equal constitutional position and the status of all the constituent peoples. ${ }^{37}$

35 The constituent status can also be interpreted as 'cultural pluralism', by which ethnic groups are designated as political units instead of individuals. See Patrick J. O'Halloran, "Post-Conflict Reconstruction: Constitutional and Transitional Power Sharing Arrangements in Bosnia and Kosovo," in From Power Sharing to Democracy: Post-Conflict Institutions in Ethnically Divided Societies, ed. Sid Noel (Montreal, Kingston, London, Ithaka: McGill-Queen's University Press, 2005), 108.

36 In line with the principle of 'constituency' as a BiH primary constitutional category that must be channelled through adequate power-sharing solutions which provide a friendly environment for unimpeded growth of both unity and diversity.

37 Dejan Vanjek, "Predstavnici i pripadnici konstitutivnih naroda - pitanje konstitutivnosti i legitimiteta," Institute for Social and Political Research (Mostar: IDPI, 2014), http://www. idpi.ba/konstitutivnost-legitimitet/. 
Thus, in political terms 'constituency' represents a form of political subjectivity and autonomy of 'a people'. In Bosnia and Herzegovina, as a multinational compound state with more than one constituent peoples, it implies equality in two key federal dimensions:

- Self-rule as autonomous decision-making on the issues relevant for preservation of integrity (self-sufficiency) of the constituent peoples (cantons and entities) and other citizens;

- Shared-rule in the sense of co-deciding powers in shared matters for all three constituent peoples.

These two dimensions basically articulate and formulate the political needs of the constituent peoples, met and managed through the application of selfrule/shared-rule principles in the federal political system. Since the constituent status belongs to each of the three peoples, it means that they should have identical or at least analogous capacities in both aspects of self- and shared-rule. Therefore, the 'constituency' is about equality, which means that without equality there can be no constituency. This further implies that any negation of equality equals the negation of constituency and therefore of the $\mathrm{BiH}$ Constitution, as well as of the DPA of which the current Constitution is a part. Without equality, the three peoples cannot be constituent, which annuls the DPA and its Constitution. Consequently, if equality remains unobserved and unassured for all the constituencies through the democratic procedures and laws, those procedures will themselves become undemocratic and unconstitutional. ${ }^{38}$ The category of 'constituency' is therefore inherent to BiH's multinational federal Constitution and supplies its underlying foundation and substance. It is a term deliberately used to emphasise group equality and assure its firm constitutional entrenchment. As such, it generates the need to align the entire constitutional and legal-political system with the principle of 'constituency' as the primary federal principle, which predetermines the multinational federal character of the country. Bosnia and Herzegovina as a post-conflict, compounded, multinational society is clearly in need of such an alignment. ${ }^{39}$

From there on, it is legitimate to consider actual institutional-regulative dispositions of shared- and self-rule and their overall distribution across

38 This primarily refers to the electoral law as the second most important act after the Constitution, which must assure that the electoral will of all constituent peoples meets fair and equal treatment.

39 Ivan Vukoja and Milan Sitarski, eds., Bosnia and Herzegovina Federalism, Equality, Sustainability: A Study of BiH Redesign to Secure Institutional Equality of Constituent Peoples (Mostar: IDPI, 2016), 207. 
the system of governance. It is up to the constituency, which is inherent to shared- and self-rule, to convert constitutional equality into institutional equality across the political system. That said, it remains to be seen how selfand shared-rule are distributed within the institutional framework in Bosnia and Herzegovina, with special emphasis on the issue of fair and equal representation of its constituent peoples. The easiest way to approach this terrain is to scrutinise key branches of governance: parliamentary and executive, and thereto related electoral provisions that have a fundamental relevance for the legitimacy of shared institutions.

The case of Bosnia and Herzegovina gives insight into how organisational asymmetries can deviate from the constitutionally ordered equality and, moreover, how the quest for symmetry can be the impetus to enhance equality and its internal balance. Already on the basic organisational level, we encounter the first prominent problem related to collective (in)equality in BiH's multinational federation. One of its two entities has a dominant Serb population (the Rs) and the other one (the Bosniak-Croat FBiH) a Bosniak ethnic majority, where there is an additional cantonal sublevel introduced to preserve balance of power amongst the two constituent peoples. ${ }^{40}$

Clearly, due to inherent structural deficiencies, the right to self-governance is unevenly allocated to the three-constituent peoples. Based on the principle of constituency, each people should dispose of similar administrative-territorial autonomy and powers in self-governance, which is currently not the case. Two entities provide institutional space and basis for the self-rule and autonomy of both Serbs (RS) and Bosniaks (FBiH), but not for the Croats who are capable of autonomous decision-making only in three cantons in which they are the majority within the FBiH. Nevertheless, cantons are positioned below entity level and as such have considerably narrower competences. ${ }^{41}$ While there is nominal balance on the federal state level, entity and cantonal levels disclose

40 Ten cantons, five with Bosniak majority, three with Croat majority and two mixed biethnic cantons.

41 Competences of all orders in Bosnia and Herzegovina are regulated by constitutions of RS, FbiH and BiH, available in English language at the OHR's web page, http://www.ohr. int/laws-of-bih/constitutions-2/. 
an obvious asymmetry, which is again particularly evident with respect to the political participation of Croats. ${ }^{42}$

The $\mathrm{FBiH}$ entity, which initially originated from the Washington Peace Agreement, had many protective mechanisms based on clear-cut consociation rules and procedures, such as vital national interests and veto powers, preallocation of highest positions, parity of ministers and top executive positions, and proportional representation. ${ }^{43}$ However, since March 1994 and until the end of 2008, a total of 109 amendments were enforced to its Constitution. ${ }^{44}$ It is highly concerning that only 36 of 109 amendments were adopted upon proposal of local administration and a successful compromise in the Parliament of that entity. All other amendments (73) were imposed by the Office of the High Representative (OHR). ${ }^{45}$ Thus, most of the decisions were arbitrary, as many of them have never been verified in the Parliament of the FBiH entity. ${ }^{46}$

Amongst other interventions in the Government of the FBiH, the abolition of ministerial parity, as well as the imposed changes of shared decisionmaking procedures in that body through $\mathrm{OHR}^{47}$ amendments in 2002, can be

42 For a recent comprehensive analysis of the political position of Croats in post-Dayton Bosnia and Herzegovina see Valentino Grbavac, Unequal Democracy: The Political Position of Croats in Bosnia and Herzegovina (Mostar: IDPI, 2016).

43 Some of the key changes which have affected the balance between these two groups, as well as its federal character - by undermining the number of power sharing instruments, checks and balances - concern: the abolition of vital national instruments, the abolition of a number of ethnic based positions (notably deputies of ministers), the introduction of majority voting instead of consensus, interference with the election process of the entire executive in the $\mathrm{FBiH}$, foremost president and deputies of the $\mathrm{FBiH}$, deviations from the principle of bicameralism whereby the upper chamber (the House of Peoples) saw less authority in deciding on the executive and in terms of constitutional changes. The judiciary was also affected. In fact, while initially the composition of the Supreme Court of the FBiH and the prosecution office relied on parity between judges of Croat and Bosniak nationality, this was later eliminated by the Office of the High Representative (онR). See Borjana Krišto and Bariša Čolak, "Inequality of Croats in Federation of Bosnia and Herzegovina," in Hrvati Bosne i Hercegovine - nositelji europskih vrijednosti?, Interdisciplinary Conference With International Cooperation, eds. Dejan Vanjek and Ivo Čolak (Neum: The Cabinet of the Croat Member of the Presidency BiH, 2017), 521-522.

44 Krišto and Čolak, "Inequality," 518.

45 Ibid.

46 Ibid.

47 International body authorised under the DPA to overlook its implementation. In 1997, OHR powers were extended to pass laws, form new institutions on the state level, alter the constitution and even dismiss officials and politicians. These practices were abolished in 2006 after numerous critiques of their colonial dispositions and failure to support proper democratic development of the country: 'The current dependence upon the oHR means that in practice the most important and powerful institution in the state is the only one 
considered as interventions in the system which are particularly harmful for equality. The consequences were that Croat ministers could not participate nor co-decide on equal footing with their Bosniak peers. In addition, many other executive functions were terminated, such as powers of ministers in the Federal Government, which supplied overall power-sharing balance, as well as the role of Government ministers in the protective mechanism of vital national interest (VNI).48 In essence, OHR impositions favoured majoritarian principles and thus undermined the position of Croats as significantly less numerous people in the FBiH. онR also intervened in the election law and competences of the House of Peoples, which were initially equal to those of the House of Representatives based on direct civic vote and mixed electoral units.

However, the most destructive interventions for equality and constituency were the amendments of the High Representative (HR) Robert Barry and his successor Wolfgang Petritsch in their involvement with electoral provisions. ${ }^{49}$ Their amendments to the Constitution of the $\mathrm{FBiH}$, as well as the election law, targeted the House of Peoples (HoP), the upper chamber of the FBiH, designed for representation of the constituent peoples and equal power sharing amongst them within the FBiH entity. Barry decided that the delegates to the HoP and its Serb, Croat, and Bosniak representatives would be elected indirectly from the ten cantonal assemblies in the FBiH Federation. He also introduced the provision that all members of cantonal assemblies can vote for all delegates who are supposed to represent Croats and Bosniaks in the HoP. Due to the numeric dominance of Bosniaks and their clear majority in five of ten cantons, this broadened their influence on the decision-making process at the expense of Croats. Namely, under those provisions Bosniak delegates and parties in Cantonal Assemblies could elect Croat delegates who were also members of dominant Bosniak parties. Barry's decision had such an impact that in 2000 it enabled the formation of a new government called the 'Alliance for Change' in the $\mathrm{FBiH}$, characterised by the total absence of any representatives of the Croat constituent people. Impositions were made under the authority of the OSCE at the time, and as such they were beyond reach of BiH's Constitutional Court. 50

that is not subject to any form of democratic accountability'; Burgess, "Territorial and Non-Territorial Identities," 23 .

48 Krišto and Čolak, "Inequality," 521.

49 A detailed account of their constitutional inpositions and interventions is provided in Vukoja and Sitarski, Bosnia and Herzegovina Federalism, Equality, Sustainability, 242.

$5^{\circ}$ Faults of the external approach to BiH state-building were rather well highlighted by Sumantra Bose who noticed that international officials very often, judging by their choice of terminology, were oblivious and insensitive to basic questions such as the nature of 
Barry's successor Wolfgang Petritsch continued in the same manner. He further changed the composition of the House of Peoples of the FBiH and devalued the constituent peoples' representation in that body. Basically, he allocated quotas to the Federation cantons. Those quotas enabled parties voted for by Bosniaks in the cantons in which Bosniaks form a clear majority to elect a two-thirds majority (12 of 17 ) of the Bosniak representatives, a two-thirds majority (12 of 17) of the Serb representatives, and five of seven representatives of 'Others'. This situation enables the Bosniaks a full control (by a two-thirds majority) of two of the constituent nations in the House of Peoples of the FBiH, the Bosniak and the Serb, and 5 of 7 representatives of 'Others. ${ }^{51}$ The result of the impositions was not only to disrupt powersharing, constituency and equality, but also to produce constant political crises in the FBiH entity. ${ }^{52}$ Those crises then radiated to the state level and

statehood and nationhood. They have rather referred to $\mathrm{BiH}$ as a national federation, whereas the reality and recent violent history suggested that it should have been treated right from the outset as a multinational federation in which three constituent peoples represent genuine agents of the federal order, in which their 'constituent' constitutional status implies the need for their full normative and practical socio-political equality. See Sumantra Bose, Bosnia after Dayton: Nationalist Partition and International Intervention (London: Hurst \& Co., 2002), 93. The similar experience of involvement and the role of international community in BiH fits also into the empirical observation encapsulated by John McGarry and Brendan O'Learry: Early consociational theory also neglected the possibilities for positive roles for outsiders both in the implementation and in the active operation of power sharing settlements'; John McGarry and Brendan O'Learry, "Consociation and its Critics: Norther Ireland after the Belfast Agreement," in Constitutional Design for Divided Societies: Integration or Accommodation?, ed. Sujit Choudhry (Oxford: Oxford University Press, 2008), 381.

51 Croats, however, cannot influence the composition amongst the Bosniak representatives because the cantons with a Croat majority only elect three of seventeen Bosniaks. In addition to their control on the election of the Bosniak, Serb and 'Others' representatives, Bosniaks can influence the composition amongst the Croat representatives. In fact, six Croat representatives are elected from the cantons with Bosniak majority, whereas only five Croat delegates are elected from the cantons with a Croat majority and six from the 'mixed ones'. Hence, from their 'own' cantons Croats can elect less than one-third of the total number of the Croat delegates ( 5 of 17 ). Altogether, this means that through this method of election, Bosniaks alone can elect the Government in the $\mathrm{FBiH}$, as well as the President and two Vice-presidents, which requires only one-third of support per each constituent people in HoP. See Vukoja and Sitarski, Bosnia and Herzegovina Federalism, Equality, Sustainability, 242.

$5^{2}$ Barry's amendments and modification of the election rules motivated the Croat political leadership in the Croat National Council to declare self-rule on 28 October 20oo, in Novi Travnik. The self-rule was intended as a protective mechanism to the constituent status of Croats. Ante Jelavić, then Croat BiH Presidency member was elected Head of Self-rule. After that, High Representative Wolfgang Petritsch used his 'Bonn powers' to 
affected overall functioning of the state. Gradual elimination of consociation contrivances, which effectively guaranteed relatively fair share of power and co-allocation of public resources amongst Croats and Bosniaks, paved the way for further centralisation that could then be unimpededly streamlined by majority ethno-political elites without external support. ${ }^{53}$

Another unparalleled phenomenon of violation of the principle of equality was the election, dominantly by Bosniak parties and voters, of the Croat member to the tripartite Presidency of $\mathrm{BiH}$, designated for representatives of the three constituent peoples. While the Serb member is elected by Serb voters from the Rs entity, the Croat and Bosniak members from the Croat-Bosniak FBiH entity are almost entirely elected by Bosniak votes. ${ }^{54}$ This was enabled by the fact that the $\mathrm{FBiH}$ entity represents a single electoral unit with a disproportionate number of Bosniak and Croat voters (approx. 75:22 \%), thus allowing Bosniaks to elect both the Bosniak and Croat member of the Presidency, and thus to gain two-thirds control of that collective institution. At the time this was the most obvious case of institutional inequality legalised by illegitimate electoral provisions inconsistent with the constitutional norm of equality of the constituent peoples. ${ }^{55}$

\subsection{On the Pathway toward Full Institutional Equality}

Following key innate and imposed inequalities, the essential challenge now is understanding how to catalyse constitutional normative symmetry of rights and entitlements within such an asymmetric organisational, institutional and electoral setting. Should the structure be altered, or should there be changes to the accepted norms? The option of dismantling 'constituency' would imply that $\mathrm{BiH}$ no longer has a multiplicity of 'demoi' but one 'demos', in which case

dismiss Jelavić from the Presidency on 7 March 2001. See Vukoja and Sitarski, Bosnia and Herzegovina Federalism, Equality, Sustainability, 239-240.

53 Bosniak politicians pursue majoritarian politics, advocate centralisation and thus tend to negate federalism in $\mathrm{BiH}$. The most prominent example is a resolution from March 2017 voted by Bosniak delegates in the House of Representatives of the Parliament of the $\mathrm{FBiH}$, by which they condemned the call for federalisation previously launched in the Resolution of the European parliament: See European Parliament, European Parliament resolution of 15 February 2017 on the 2016 Commission Report on Bosnia and Herzegovina (2016/2313(INI)), last updated 5 April 2018, http://www.europarl.europa.eu/sides/getDoc. do?pubRef=-//EP//TEXT+TA+P8-TA-2017-Oo37+O+DOC+XML+Vo//EN. These tendencies are well explained in Keil, Multinational Federalism, 172.

54 Vukoja and Sitarski, Bosnia and Herzegovina Federalism, Equality, Sustainability, 258.

55 The political dialogue between Bosniak and Croat political representatives has been without success for several years, which is a latent threat to the democratic functioning and stability of the $\mathrm{FBiH}$ and $\mathrm{BiH}$. 
majoritarian democracy would appear as a logical choice. The suspension of constituency would then unlock transformation of the country from a federal to a unitary setting, but also pave the way for domination of numerically dominant people(s). Still, even unitarisation of the constitutional framework could not alter BiH's multinational character on a societal level, nor could it alter the three already formed co-nations ${ }^{56}$ - Bosniaks, Serbs and Croats.

In legal terms, radical transformation of the constitutional setting would require overwhelming support and mutual consensus of all three constituent peoples, which is unlikely to happen. In fact, while it could be attained through coercion which might then lead to violence, it is rather difficult to imagine that structured social groups should self-willingly accept deprivation of their political subjectivity, constitutional status, existence and identity. Also, a thorough reorganisation of the country would be very complex and demanding for $\mathrm{BiH}$ as a post-conflict society. In fact, $\mathrm{BiH}$ is characterised by a significant lack of common understanding of the shared political community, as well as a lack of political will and culture needed to overcome the power asymmetries embedded within the existent legal-constitutional and institutional framework. Such an agreement or consensus between the representatives of the constituent peoples has proven to be a hard case. ${ }^{57}$

For said reasons, it is more advisable to pursue another scenario and reexamine the relation of the key constitutional norms with everything that lies below, namely to align and harmonise the entire legal-political system with the Constitution and its fundamental category of the 'constituency/equality'. The previously described asymmetry in the applicative capacities of the three constituent peoples' right to self-governance suggests that there should be an applied symmetry to support balancing a highly asymmetric system. But what tools are available to bolster symmetry and equality without engaging in a structural redefinition of the whole arrangement, which is basically a locked peace treaty that is extremely hard to replace by a new constitutional contract? The least challenging and least disturbing pathway would be to follow what is already implicit to the existent Constitution and its underlining peace agreements - the pathway of constituency and institutional equality. This means

$5^{6} \quad$ Term used to denominate the three constituent peoples in Mile Lasić, "Konsocijacija ne znači podjelu zemlje kako tvrde neuki," Digitalna demokracija (2018), https://digitalnademokracija.com/2018/o6/22/mile-lasic-konsocijacija-ne-znaci-podjelu-zemlje-kakotvrde-neuki/.

57 There were several unsuccessful attempts to change the constitutional framework with the assistance of the international community, resulting in failed initiatives for constitutional reforms (April - 2006, Prud - 2008, Butmir - 2009). 
that it is only through the advancement of symmetry within the shared institutions in which all constituencies meet, interact, cooperate and co-decide, that $\mathrm{BiH}$ 's locked structural inequality expressed through its organisational asymmetry (two entities - three constituent peoples) could be rectified or mitigated. In that sense, the focus on institutional equality could efficiently compensate for the present structural deficiencies, which were embedded through peace agreements primarily designed to stop the war, but not to protect equality.

If the main purpose is to avoid reorganising the structure of the country and avoid interventions to the substance of the Washington and Dayton peace agreements, the pathway to compensate the overall asymmetry would be a re-enhancement of the position of 'minorities' through consociational contrivances such as targeted functions, rules, procedures and regulations. A first step in that respect would be to conduct a thorough analysis of the constitutionally controversial international impositions, and consequently the revision and reversal of all those that purportedly undermine constitutional equality in terms of symmetric allocation of self-rule capacities between the constituent peoples. That would entail re-examining and reemploying the following protective measures in support of constitutional equality: 1. a guaranteed minimum representation, 2. veto power and an effective protection of the vital national interest, ${ }^{58}$ 3. a broad and inclusive coalition, required

$5^{8}$ Vital national interest (VNI) is constitutionally regulated mainly on the State level and it defines the role of the Parliamentary Assembly of Bosnia and Herzegovina. More specifically, it is assigned under auspices of the House of Peoples of the Parliamentary Assembly of $\mathrm{BiH}$ and includes detailed procedures: 'Protection of the vital national Interest [:] A proposed decision of the Parliamentary Assembly of BiH in the House of Peoples can be declared destructive to the vital national interest of the Bosniak, Croat, or Serb people by a majority votes from the Bosniak, Croat or Serb delegates. Such a proposed decision has to be approved by the House of Peoples by a majority of Bosniak, Croat, and Serb delegates who are present and voting. In case the majority of Bosniak, Croat or Serb delegates object to an invocation of the vital national interest, the Speaker of the House of Peoples will immediately convene a Joint Commission consisting of three delegates, each elected amongst Bosniak, Croat, and Serb delegates, in order to resolve the issue. If the Commission fails to resolve the issue within five days, the case will be transferred to the BiH Constitutional Court which will review the procedural correctness of the matter, under emergency procedure. ' See Article IV of the Constitution of Bosnia and Herzegovina, available at http://www.ohr.int/ohr-dept/legal/laws-of-bih/pdf/oor\%2o\%2oConstitutions/BH/BH\%2oCONSTITUTION\%2o.pdf.

Furthermore, under the Constitution of the FBiH entity, the issue of VNI is more clearly specified, including: 'Exercise of the rights of constituent peoples to be adequately represented in legislative, executive and judicial authorities; identity of one constituent people; constitutional amendments; organization of public authorities; equal rights of constituent peoples in the process of decision-making; education, religion, language, 
to maintain stability of interethnic relations and prevent conflicts, 4. a consensual decision-making or decision-making through supermajorities of all three constituent peoples representatives (most of all in BiH Presidency and the House of Peoples - both in the federated entity, as well as on BiH's federal level), 5. a proportional representation on the professional administrative level, 6. parity on higher administrative levels, and 7. an electoral law whose design protects and ensures faithful representation of each of the constituent peoples following the relevant decision of the BiH Constitutional Court. ${ }^{59}$ This would preclude potential governments deprived of democratic legitimacy, i.e. prevent the possible exclusion of any of the three constituents in participating and co-deciding in shared-rule matters.

The premise is that the synchronised application of fair electoral provisions will enable the operationalisation of the shared-rule principle in line with 'constituency', creating what is colloquially known as institutional equality. ${ }^{60}$ This strategy would compensate structural-organisational asymmetries ascertained in the segment of self-rule, by relying on already existent constitutional principles of BiH's multinational federation. The key instrument of transposition of those principles into the reality of political life is electoral law. Electoral law must thus protect the integrity (autonomy) of each constituency and assure its participation in any key decision-making process. While the constituent peoples are the primary agents of BiH's multinational federal order, the entities and cantons have an organizational role, which is to provide a fair and functional system of governance capable of protecting equality of the three constituent peoples and 'Other' citizens. In order to do so, the state's legal-political life and the political organisation need, however, to faithfully reflect their political will. It stems from this that there must be a

promotion of culture, tradition and cultural heritage; territorial organization; public information system and other issues treated as of vital national interest if so claimed by $2 / 3$ rd of one of the caucuses of the constituent peoples in the House of Peoples. ' Procedures are somewhat different than in the case of the State level HoP.

For detailed references, see Constitution of the Federation of Bosnia and Herzegovina Articles 17. and 18., available at http://www.ohr.int/laws-of-bih/constitutions-2/.

Democratic legitimacy by standards and merits of the BiH Constitution and Constitutional Court imply the right of each constituent people to elect representatives of its political will: [T] he Election Law must follow the logic of legitimate representation of the constituent peoples, in particular when it comes to the houses of peoples, i.e. that body of power which is intended to protect and articulate specific interests and needs of each constituent peoples'; Constitutional Court of Bosnia and Herzegovina, Judgment no. U-23/14, 'Ljubic', Sarajevo, 1st December 2016, http://www.ccbh.ba/odluke/. 
clear correlation between the Constitution, the laws, all bodies of governance and the 'constituencies'. Such relations must be set forth unambiguously in the electoral law.

This point is best seen in the example of the still unimplemented ${ }^{61}$ decision of BiH's Constitutional Court U-23/14 ('Ljubić'). ${ }^{62}$ The central issue the appeal tackled was the problematic provisions regulating the composition and methodology of the election of the delegates representing the Bosniaks, Croats and Serbs of the House of Peoples of the Parliament of the FBiH. The Court ruled that the election law violates the principle of the constituent status of peoples, i.e. leads to inequality between any of the constituent peoples, thereby violating Article I(2) the Constitution of Bosnia and Herzegovina: ${ }^{63}$ There was an ascertained mismatch of the number of Serb, Croat and Bosniak delegates in the HoP, indirectly elected in ten cantonal assemblies, and the ethnic composition of the cantons from which they were elected. The fixed delegate quotas reserved for each of the constituent peoples in the cantons caused huge disproportions between the size of 'constituent peoples' and the number of seats allocated to them. This resulted in cases of both overrepresentation and underrepresentation, which undermined the democratic legitimacy, as well as the federal principle of equality. Thus, the Court concluded that the principle of the constituent status of peoples in the Federation, in the context of House of Peoples, may be realized only if a seat in the House of Peoples is filled based on precise criteria that should ensure full representation of each constituent people in the Federation.' ${ }^{64}$

61 Since 2016, it has been the subject of unsuccessful interparty negotiations between the two largest national parties of Croats and Bosniaks in the FBiH entity, the Croatian Democratic Union of Bosnia and Herzegovina (HDZ) and Bosniak Party of Democratic Action (SDA).

62 On 20 September 2014 Dr. Božo Ljubić, the Speaker of the House of Representatives of the Parliamentary Assembly of Bosnia and Herzegovina at the time of the submission of the request ('the 4 applicant'), filed with the Constitutional Court of Bosnia and Herzegovina ('the Constitutional Court') a request for a review of the constitutionality of Articles 10.10, 10.12, 10.15 and 10.16 of the Subchapter B of the Election Law of Bosnia and Herzegovina (Official Gazette of BiH, 23/o1, 7/02, 9/o2, 25/O2, 4/04, 20/04, 25/05, 52/05, 65/05, 77/05, 11/ o6, 24/06, 32/o7, 33/08, 37/08, 32/10, 18/13, 7/14 and 31/16, hereinafter: 'the Election Law') and the provisions of Article 20.16A under Chapter 20 - Transitional and Final Provisions of the Election Law. See Constitutional Court of Bosnia and Herzegovina, Judgment no. U-23/14, 'Ljubic', 2, Sarajevo, 1st December 2016, http://www.ccbh.ba/odluke/.

63 Constitutional Court of Bosnia and Herzegovina, Judgment no. U-23/14, 'Ljubic', 26, Sarajevo, 1st December 2016, http://www.ccbh.ba/odluke/.

64 Constitutional Court of Bosnia and Herzegovina, Judgment no. U-23/14, 'Ljubic', 26, Sarajevo, 1st December 2016, http://www.ccbh.ba/odluke/. 
Furthermore, the Court extended the principle of democratic representation of constituent peoples to all administrative-political levels ${ }^{65}$ as a general requirement of the electoral process in $\mathrm{BiH}$, understood as a multinational country. It had also related the term of 'legitimate representation' of constituent peoples to all institutions designed to meet the specificities of Bosnia and Herzegovina, foremost the country level HoP and the tripartite Presidency of BiH. ${ }^{66}$ This was entirely the opposite of the earlier considered impositions made by HR s Barry and Petritsch, which blatantly bypassed the principles of constituency, equality, and legitimacy with regard to the representation of the three constituent peoples. ${ }^{67}$ As a matter of fact, the Court unequivocally contested and overruled Petritsch's impositions simply by referring to the 'constituency' and the right of each constituent people to elect its political representatives pursuant to the democratic right to free and fair elections. This further implied that the electoral provisions had to be brought into line with the principle of 'constituency', the latter being understood as an overarching constitutional principle with primacy over all other laws and regulations. ${ }^{68}$

\subsection{How to Fit the Rights of 'Others' into the BiH Constitution}

The BiH Constitution unites both the communitarian principle of 'constituency' and liberal human rights norms, given the fact that the European Convention on Human Rights is part of BiH's constitutional framework. At first glance they seem to be incompatible. In fact, the norm of 'constituency' and equality appear as exclusive attributes of the three constituent peoples, leaving thereby all other minorities and citizens unprotected and deprived of their political rights. A society in which there are privileged and disadvantaged groups is naturally unacceptable from the point of view of the liberal notion of fairness and justice. Thus, it appears that 'Others' is the only constitutional category of BiH's population which is unprotected in the social-political life of the country. Since BiH does not fully protect the rights of 'Others', there is a need

65 ' $[\mathrm{T}]$ he connection between those who are represented and their political representatives at all administrative-political levels is actually the one that gives the legitimacy to community representatives. Therefore, only the legitimacy of representation creates a basis for actual participation and decision-making; Constitutional Court of Bosnia and Herzegovina, Judgment no. U-23/14, 'Ljubic', 24, Sarajevo, 1st December 2016, http://www. ccbh.ba/odluke/.

66 Constitutional Court of Bosnia and Herzegovina, Judgment no. U-23/14, 'Ljubic', 24, Sarajevo, 1st December 2016, http://www.ccbh.ba/odluke/.

67 Already examined interventions in the electoral regulative by HR Wolfgang Petritsch.

68 This has been already laid down with the Constitutional Court of Bosnia and Herzegovina in its Judgment no. U-5/98, 'On Constituency', http://www.ccbh.ba/odluke/. 
for stronger involvement of international authorities, such as the European Court of Human Rights (ECHR).

But who are the 'Others' in the BiH Constitution? Under the 2013 population census, 'Others' appears as a heterogeneous category which comprises less than $3 \%$ of the total population. ${ }^{69}$ It incorporates minority groups and citizens unaffiliated to any of the constituent peoples who have declared their identity in some other way. It also comprises seventeen national minorities recognised under the existent Law on national minorities, ${ }^{70}$ as well as citizens with versatile selfdenominations e.g. Bosnians, Herzegovinians, humans, or Martians. Although heterogeneous in regard to all the identities it comprises, 'Others' is still an explicit constitutional category. As such, the rights of its members must be protected both under BiH's Constitution and under laws and external instruments. In that sense, the rights of 'Others' are not entirely unprotected in an administrative sense: there are preassigned formal quotas in civil service for them, anti-discrimination laws and institutions (e.g. Ombudsman) which treat them as well as any other citizen of $\mathrm{BiH}$; there is also a Council of National Minorities within the Parliamentary Assembly of Bosnia and Herzegovina, and reserved seats for them in cantonal assemblies. ${ }^{71}$

However, the neuralgic point of discrimination and inequality of 'Others' resides in the domain of political participation, especially within the specific consociate institutions primarily designed to represent constituent peoples and to assure power-balance amongst them. In this respect, there have been several decisions by the ECHR against Bosnia and Herzegovina, in which it was found that minorities were discriminated against and prevented from running for or being elected to BiH's Presidency and country-level upper chamber, the House of Peoples. The ECHR found roots of this inconvenience in articles IV and $\mathrm{v}$ of BiH's Constitution, which were copied to formulate the election law and reserved the right to candidacy only for Croats, Serbs and Bosniaks. The Court found that it was incompatible with Article 14 of the European Human Rights Convention and its Protocols 1 and $12 .{ }^{72}$

69 See Agency for Statistics of Bosnia and Herzegovina, "Census of Population, Households and Dwellings in Bosnia and Herzegovina: Ethnicity/National Affiliation, Religion and Mother Tongue", Sarajevo, 2019, 23.

70 Adopted by the Parliamentary Assembly of $\mathrm{BiH}$ at the session of the House of Representatives held on 20 June 2002 and the House of Peoples at its session held on 12 April 2003; available in English at https://advokat-prnjavorac.com/legislation/LAW_ ON\%2ORIGHTS_OF\%2ONATIONAL_\%2OMINORITIES_BOSNIA.pdf.

71 But not in all ten cantonal assemblies, and not at all in municipality councils.

72 However, the implementation of the relevant ECHR judgments is still pending, mostly due to stand-offs between Croat and Bosniak political representatives in resolving these 
The most prominent case adjudicated by the ECHR is Sejdić-Finci v. BiH. In this case Mr. Dervo Sejdić, as a Roma, and Mr. Jakob Finci as a Jew, both belonging to the constitutional category of 'Others', filed a complaint with the Constitutional Court of $\mathrm{BiH}$ (cC). In its reply the CC ascertained that there was no violation of the Constitution, justifying it with its competences in due relation to specificities related to $\mathrm{BiH}$ as a post-conflict society and its powersharing arrangement. After that, the case was delegated to the ECHR, which targeted provisions of the Constitution and the election law requiring that candidates to country level HoP and the Presidency BiH could only be members of the three constituent peoples who reside in the specific administrative/ electoral units (FBiH or RS entities). This further implied that there was, and still is, discrimination against 'Others' both on the grounds of their identity and place of residence. ${ }^{73}$ In yet another case, $\mathrm{Pilav} v$. BiH, the same problem of discrimination and human rights violation was also ascertained for members of constituent peoples and their 'dislocated' minority communities. ${ }^{74}$

However, the ECHR's elaboration in Sejdić-Finci contains an interesting section, which provokes wider deliberations on general prospects of coexistence between human rights and power-sharing norms within the same constitutional framework:

When the impugned constitutional provisions were put in place a very fragile ceasefire was in effect on the ground. The provisions were designed to end a brutal conflict marked by genocide and 'ethnic cleansing'. The

matters. For years they have been entrenched in opposite positions on how these decisions should be implemented in conjunction with the constitutional principle of democratic representation of the constituent peoples.

73 The place of residence as discriminatory was central in the case Pilav v. BiH because, under the current provisions, a member of BiH's Presidency from the territory of the Republika Srpska entity must be an ethnic Serb. Since Mr. Ilijas Pilav declared himself as a Bosniak, his candidature was rejected by the Electoral Committee and by the Court with the same arguments as in the case of Sejdić-Finci. The other two prominent cases are Zornic v. BiH and Slaku v. BiH, but they are analogous to the Sejdić-Finci case as both Ms. Zornic and Slaku could not be accepted as candidates for the election in the HoP and the Presidency, because they are not members of the constituent peoples.

74 'There is no dispute that the provision of Article $\mathrm{v}$ of the Constitution of Bosnia and Herzegovina, as well as the provision of Article 8 of the Election Act 2001 have a restrictive character in a way that they restrict the rights of citizens with respect to the candidacy of Bosniaks and Croats from the territory of the Republika Srpska and the Serbs from the territory of the Federation of Bosnia and Herzegovina to stand for election as members of the Presidency of Bosnia and Herzegovina.'; Constitutional Court of Bosnia and Herzegovina cited in European Court of Human Rights, Pilav v. Bosnia and Herzegovina (application no. 41939/o7), judgment of 9 June 2016, 14. 
nature of the conflict was such that the approval of the 'constituent peoples' (namely, the Bosniaks, Croats and Serbs) was necessary to ensure peace. This could explain, without necessarily justifying, the absence of representatives of the other communities (such as local Roma and Jewish communities) at the peace negotiations and the participants' preoccupation with effective equality between the 'constituent peoples' in the post-conflict society. ${ }^{75}$

The general critique of ethnic power-sharing and consociation is implicit to this statement, which might be seen both as excessive and superfluous in the attempt to explain the causes of the specific problem brought before the ECHR. Such a reaction is not unexpected or surprising as it comes from a court designed to deal with violations of human rights. If the ECHR had asked for assistance from a neutral expert organisation such as the Council of Europe's Venice Commission, this might have contributed to a better understanding of the specifics of BiH's constitutional, legislative and institutional settings, and would have perhaps discouraged such a statement in the first place. The Venice Commission would have probably declared what it had previously said, which was to acknowledge the multinational character of the country and its specifics, e.g. by saying: 'But, the concepts of equal voting power do not apply to the special parts of the BiH legislature, since they are to represent constituent peoples - and hence are designed to meet the unique specificities of $\mathrm{BiH}^{\prime}{ }^{\prime 6} \mathrm{In}$ fact, hardly any post-conflict arrangement with elements of consociation and ethnic federalism could be entirely exempted from human rights critique. ${ }^{77}$ For those reasons, the ECHR's statement is more precarious than it seems at first glance. If power-sharing arrangements are bound to be abandoned one day, then it is hard to expect that anyone would accept them in the future as an interim tool. This point is highlighted by Christopher McCrudden and Brian O'Leary who state that:

75 European Court of Human Rights, Grand Chamber, Sejdić and Finci v. Bosnia and Herzegovina (application nos. 27996/06 and 34836/o6), judgment of 22 December 2009, 33 .

76 European Commission For Democracy Through Law (Venice Commission), Opinion 862/ 2016 on the mode of election of delegates to the House of Peoples of the Parliament of the Federation of Bosnia and Herzegovina of 29 September 2016, 12.

77 For closer reference please see subtitle 'Consociations and Human Rights Standards' in Christopher McCrudden and Brendan O'Leary, "Courts and Consociations, or How Human Rights Courts May De-stabilize Power-sharing Settlements," The European Journal of International Law 24, no. 2 (2013): 484/485, available at https://doi.org/10.1093/ejil/ chto2o. 
[A]lthough the Court's decision indicates one possible trajectory of human rights courts' reactions to consociations, this would be an unfortunate development because it leaves future negotiators in places riven by potential or manifest bloody ethnic conflicts with considerably less flexibility in reaching a settlement. That in turn may unintentionally contribute to sustaining such conflicts and make it more likely that advisors to negotiators will advise. ${ }^{78}$

Both approaches need to be accounted for and neither of them discarded in order to avoid potentially disturbing effects, which are inevitable in cases where human rights authorities scrutinise power-sharing systems. Both the authority of Courts and internal stability of post-conflict power-sharing arrangements should be protected. Not doing so would jeopardise not only the success of conflict resolution and management, but also human rights instruments. But how is it possible to reconcile two norms appearing to be incompatible within one single constitutional framework? To pursue either one or the other could lead to outcomes which could in a post conflict-riven society such as $\mathrm{BiH}$, undermine the consolidation of its constitutional framework. ${ }^{79}$ Thus there must be a 'third' way to escape this perilous liberal-communitarian conundrum and open the path for convergence of these two opposed normative poles. First, from a practical point of view, human rights decisions should be narrowed down as much as possible to a specific problem. Therefore, any criticism to federalism should not simplistically state that power-sharing is hostile to human rights, which would be redundant and counterproductive. Instead, a proper critique should start by acknowledging that in its decision, the ECHR processed individual requests of applicants prevented from being candidates - as members of minority groups - and in that way were prevented from exercising their human, civic and political rights. Each judicial problem requires concrete solutions and as such it should be treated with due sensibility, without engaging in broader ideological and political controversies. It is thus untenable and unforeseeable to search for ready-made solutions in past human rights trials, as this can affect prospects for successful accommodation

78 Christopher McCrudden and Brendan O'Leary, "Courts and Consociations", 477.

79 The difference between collectivist and individualist approaches has been well explained in Will Kymlicka, Multicultural Citizenship, A Liberal Theory of Minority Rights (Oxford: Clarendon Press, 1995), 47. Kymlicka calls their fight over primacy 'an old and venerable in political philosophy, but unfruitful'. Neither can individual rights be reduced or consumed entirely through those of the group, nor can group rights be reduced and consumed through individual ones. 
of human rights within a delicate power-sharing setting. A minimum of awareness about the peculiarities of each individual social-political system must be considered as proceeding from its own ideological construction. A contextinsensitive approach might, though perhaps unintentionally, undermine the core principles upon which peace and stability are founded. ${ }^{80}$

On the other hand, power-sharing systems must be flexible and open to human rights but not at the expense of the core constitutional values that hold the system together. This further implies the need for a careful reading and full respect of the fundamental constitutional values, also by means of constitutional hermeneutics and teleology, if necessary. The affirmation of constitutional values does not only support constitutionalism as such and the rule of law, but it also makes way for accommodation of key ECHR requirements. In BiH, such constitutional principles are constituency/equality, institutional equality via symmetry, the credible and faithful democratic representation of the three constituent peoples and the political inclusion of 'Others'. Those values and principles must be interconnected and justifiable under the 'constituency' as a superimposed constitutional value. The traditional constitutional principle of 'constituency' as such must be kept and mirrored in all the structures of governance and institutions designed for collective representation, as we already debated for the HoP and the Presidency. It means that the ECHR rulings can be fulfilled, without destroying the entire power-sharing system, only under the condition that the 'constituency' and the 'democratic representation' of the constituent peoples as bearers of BiH's constitutional order are fully respected. ${ }^{81}$

Thus, in practical terms, the 'mid-path' between power-sharing and human rights in BiH would require shifting focus from an ethnic-based participation towards a democratic representation of the constituent peoples, as provided in the U-23/14-ruling ('Ljubić'). De-ethnicisation of the executive and legislative positions in Presidency and the HoP would eliminate the problem of identitybased discrimination and assure that any citizen could be a candidate and be elected as a member of collective institutions. ${ }^{82}$ Conversely, institutional

8o Questioning core constitutional principles upon which an entire legal-political order is based is precarious in many ways, both for that order and the involved external authority.

81 Ivan Vukoja and Milan Sitarski, "Constitutional, Legal and Political Algorithm of the Electoral Reform in Bosnia and Herzegovina," Mostariensia - Journal of Social Sciences and Humanities 22, no. 1 (May 2018): 519.

82 Which is exactly what the ECHR requested in its key judgments v. BiH. For instance, amongst others, the ECHR judgment in the prominent Sejdić-Finci case highlights the obligation of Bosnia and Herzegovina as a member of the Council of Europe to amend its constitution in view of replacing the mechanisms of ethnic representation by representation based on the civic principle. See European Court of Human Rights, 
equality between the constituent peoples would also be protected by allowing them to connect to collective institutions through an unhindered projection of their political will in elections. Each of them would still retain ownership over preassigned positions in the collective bodies of the Presidency and the HoP, but unladen with any current requirement of ethnic identification as current mandatory criteria for entering these positions. ${ }^{83}$ It means that the Serb, Croat and Bosniak members of the Presidency, as well as the Serb, Croat and Bosniak delegates in the respective ethnic group in the HoP, could become candidates supported either directly by their respective constituency (for members of the Presidency), or indirectly by the representatives of the constituent people in the cantonal assemblies (for the HoP delegates). The 'Others' could then be free to be a candidate or vote for any of the said positions they chose to. Since there are already fully worked-out concrete solutions and proposals leading in this direction, ${ }^{84}$ this chapter has not focused on this option in detail.

This all points out, on the one hand, the merits of the decision of BiH's Constitutional Court on the 'legitimate representation' of constituent peoples (U-23/14, 'Ljubić') and, on the other hand, that the EcHR's judgments can be fulfilled within the current power-sharing arrangement. ${ }^{85}$ In essence, they are not necessarily contradictory but complementary, and as such they can simultaneously coexist and develop within the existent $\mathrm{BiH}$ constitutional framework. The benefit of such a conjunctive strategy is that it retains the integrity of the constitutional framework by affirming its corporate-federal dimension (Constituency of the Constituent Peoples) at the expense of the explicit-consociate (ethnically preassigned public-political positions), without, however, usurping the essence of power-sharing agreement as defined in the Constitution and preceding peace treaties. This could be a sound alternative to any biased or exclusivist approach pointed either against group or individual rights, which would then lead to an insurmountable constitutional deadlock. Therefore, the only requirement for the success of this strategy is a deep reading of BiH's Constitution and its values in conjunction with relevant decisions of BiH's Constitutional Court and vice versa. That is the prerequisite

Sejdić-Finci v. Bosnia and Herzegovina (application nos. 27996/o6 and 34836/o6), Strasbourg, Judgment of 22 December 2009, 16.

83 This approach is reflected and applied in a most meaningful way to the issue of BiH's electoral reform by the Institute for Social and Political Research (IDPI) in the article "Basic Principles, Models and Proposals for BiH Election Law Reform", Mostar - BiH, April $5_{\text {th }}$ 2018, available in English at http://www.en.idpi.ba/basic-principles-models-andproposals-for-bih-election-law-reform/.

84 Vukoja and Sitarski, "Constitutional, Legal and Political Algorithm," 505-521.

85 Vukoja and Sitarski, "Constitutional, Legal and Political Algorithm," 519. 
of a non-invasive implementation of the ECHR's decisions, and the path enabling the reconciliation of individual and group rights in the $\mathrm{BiH}$ multinational federation.

It follows that an impasse of the asymmetric structural deficiencies, embedded in $\mathrm{BiH}$ dyadic two-entity territorial organisation (three constituent peoples - two entities), ought to be compensated through other available means of the soft, i.e. non-structural, power-sharing contrivances, in order to affirm equal political participation in the decision-making processes of all the $\mathrm{BiH}$ constituents regardless of their size, demographic positioning, or political or economic power. The effects and consequences of the structural inequalities embedded in the Dayton Peace Agreement and further developed during its internationally supervised implementation could be remedied via adequate compensational policies in the institutional-regulative sphere. This could be achieved by re-affirming the electoral and consociate rules for the empowerment of minorities and betterment of their overall institutional position under a given constitutional setting. To honour mandatory constitutional norms of equality of all the constitutional-political entities, ${ }^{86}$ optimal standards of relative symmetry and connected institutional equality must be advanced.

Two key aspects of inequality in the $\mathrm{BiH}$ multinational federation have been examined in this chapter. The first predominantly relates to equality between constituent peoples (Serbs, Croats and Bosniaks), and the second to the position and equality of 'Others'. Regarding the first aspect, the constituent peoples are in fact constituent members and the backbone of the $\mathrm{BiH}$ multinational federation. They are the founding basis of BiH's current powersharing arrangement. Thus, the concept of 'constituency' as a key constitutional principle supersedes all other constitutional provisions and laws. As such it presupposes the equality of the constituent peoples (Croats, Bosniaks and Serbs) and the corresponding symmetric application of their rights both in the shared- and self-rule segments. Self- and shared-rule as federal principles are implicit to 'constituency', and as such play a crucial role in delivering equality in the $\mathrm{BiH}$ multinational federation. After an overview of the participative and co-decision-making capacities of the three constituent peoples, it was ascertained that in the current situation and on multiple levels of BiH's

86 In the case of $\mathrm{BiH}$, three constituent peoples and other citizens. 
governance apparatus, the executive and legislative powers do not faithfully reflect, as they should, the constitutional principle of symmetry, embedded in the principle of 'constituency'. There are conspicuous asymmetries within the power-sharing system which deviate from the constitutional norm of 'constituency'. This essentially refers to Croats who are the least numerous community in $\mathrm{BiH}$ and hold significantly lower self- and shared-rule capacities than the other two constituent peoples. In that respect, BiH's electoral law is still controversial as it does not guarantee Croats from the $\mathrm{FBiH}$, or minorities in both entities, the election of their representatives to BiH's Presidency and HoP. The examined cases of inequality require a revision of power-sharing mechanisms so that constitutional symmetry and equality in the segment of shared-rule can become an institutional reality and thus compensate embedded structural asymmetries. Another aspect of inequality, related to human rights and the still unimplemented ECHR decisions against BiH, indicates that minorities and individuals from the category of 'Others' are also discriminated against on the grounds of their identity and place of residence. To resolve those pertinent problems of inequality in both collective and individual dimensions, it is necessary to respect both the BiH Constitution and the traditional value of 'constituency', which implies that collective equality and human rights norms from the European Convention on Human Rights are integrated into BiH's constitutional framework. Consequently, BiH must implement the 'Ljubić' decision of the Constitutional Court on legitimate representation of the constituent peoples and revise the asymmetric distribution of public positions between their political representatives. It must also implement ECHR decisions targeting problems of discrimination of minorities and 'Others' as non-constituents. In order to do so, it must abandon ethnic identity as the criteria for candidacy in collective representation institutions - $\mathrm{BiH}$ Presidency and the House of Peoples. The key point is that both individual and group equality can be fixed only under the auspices of the extant constitutional framework and its key value - 'constituency'. Human rights norms can be accommodated without overall disruption of the power-sharing balance created under the DPA and the appertaining Constitution. This is the only way to avoid continued perilous and unpredictable trade-offs between stability and democracy.

\section{Bibliography}

Bermeo, Nancy. "The Import of Institutions." Journal of Democracy 13, no. 2 (April 2002): 96-110. 
Bose, Sumantra. Bosnia after Dayton: Nationalist Partition and International Intervention. London: Hurst \& $\mathrm{Co}, 2 \mathrm{OO}$.

Burgess, Michael, Comparative Federalism: Theory and Practice. London, New York: Routledge, 2006.

Burgess, Michael. "Territorial and Non-Territorial Identities: Multinational Federalism in Multinational Federation." Paper prepared for the Conference 'Multinational Federalism in Perspective: A Viable Model?', Université du Quebec à Montreal (UQAM), Montreal, Quebec, Canada (Canterbury: Centre For Federal Studies, Rutherford College, University of Kent, 2009). https://www.academia.edu/1471289o/Territorial_and_NonTerritorial_Identities_Multinational_Federalism_in_Multinational_Federation.

Burgess, Michael. In Search of the Federal Spirit: New Theoretical and Empirical Perspectives in Comparative Federalism. Oxford: Oxford University Press, 2012.

Choudhry, Sujit. "Bridging Comparative Politics and Comparative Constitutional Law: Constitutional Design in Divided Societies." In Constitutional Design for Divided Societies: Integration or Accommodation?, edited by Sujit Choudhry, 3-40. Oxford: Oxford University Press, 2008.

Elazar, Daniel J. Exploring Federalism. Tuscaloosa: University of Alabama Press, 1987.

Fleiner, Thomas. Dynamics of Shared Rule in Federations. March 2005. www.thomasfleiner.ch/files/documents//Dynamics.pdf.

Fleiner, Tomas, and Lidija Basta. Constitutional Democracy in a Multicultural and Globalized World. Berlin, Heidelberg: Springer-Verlag, 2009.

Gagnon, Alain. "The Moral Foundation of Asymmetrical Federalism: A Normative Exploration of the Case of Quebec and Canada." In Multinational Democracies, edited by Alain Gagnon and James Tully. Cambridge: Cambridge University Press, 2001, 319-336.

Grbavac, Valentino. Unequal Democracy: The Political Position of Croats in Bosnia and Herzegovina. Mostar: ID PI, 2016.

Ignatief, Michael. The Right Revolution. Toronto: House of Anansi Press Ltd, 2001.

Keil, Soeren. "Federalism as a Tool of Conflict-Resolution: The Case of Bosnia and Herzegovina." L'Europe en formation, no. 1 (2012): 205-218.

Keil, Soeren. Multinational Federalism in Bosnia and Herzegovina. London and New York: Routledge, 2016.

King, Preston. Federalism and Federation. London: Crom Helm, 1982.

Krišto, Borjana, and Bariša Čolak. "Inequality of Croats in Federation of Bosnia and Herzegovina." In Hrvati Bosne i Hercegovine - nositelji europskih vrijednosti?, Interdisciplinary Conference with International Cooperation, edited by Dejan Vanjek and Ivo Čolak, 516-527. Neum: The Cabinet of the Croat Member of the Presidency $\mathrm{BiH}, 2017$.

Kymlicka, Will. Multicultural Citizenship, A Liberal Theory of Minority Rights. Oxford: Clarendon Press, 1995. 
Lasić, Mile. "Konsocijacija ne znači podjelu zemlje kako tvrde neuki." Digitalna demokracija (2018). https://digitalnademokracija.com/2018/o6/22/mile-lasic-konsocijacija-ne-znaci-podjelu-zemlje-kako-tvrde-neuki/.

McCrudden, Christopher, and Brendan O'Leary. "Courts and Consociations, or How Human Rights Courts May De-stabilize Power-sharing Settlements.” The European Journal of International Law 24, no. 2 (2013): 477-501. https://doi.org/10.1093/ejil/ chto2o.

McGarry, John, and Brendan O'Learry. "Consociation and its Critics: Norther Ireland after the Belfast Agreement." In Constitutional Design for Divided Societies: Integration or Accommodation?, edited by Sujit Choudhry, 369-408. Oxford: Oxford University Press, 2008.

McGarry, John, and Brendan O'Leary. "Federation as a Method of Ethnic Conflict Regulation.” Forumfed.org (2004). http://www.forumfed.org/libdocs/Misc/o4O1-intMcGarry-OLeary.pdf.

O'Leary, Brendan. "Debating Consociational Politics: Normative and Explanatory Arguments." In From Power Sharing to Democracy: Post-Conflict Institutions in Ethnically Divided Societies, edited by Sid Noel, 3-43. Montreal, Kingston, London, Ithaca: McGill-Queen's University Press, 2005.

O'Halloran, Patrick J. "Post-Conflict Reconstruction: Constitutional and Transitional Power Sharing Arrangements in Bosnia and Kosovo." In From Power Sharing to Democracy: Post-Conflict Institutions in Ethnically Divided Societies, edited by Sid Noel, 104-119. Montreal, Kingston, London, Ithaka: McGill-Queen's University Press, 2005 .

Rosenberg, Sheri P. "Promoting Equality after Genocide." Tulane Journal of International and Comparative Law (2007), 329-343.

Vanjek, Dejan. "Predstavnici i pripadnici konstitutivnih naroda - pitanje konstitutivnosti i legitimiteta." Institute for Social and Political Research. Mostar: ID PI, 2014. http://www.idpi.ba/konstitutivnost-legitimitet/.

Vukoja, Ivan, and Milan Sitarski, eds. Bosnia and Herzegovina Federalism, Equality, sustainability - A study of BiH Redesign to Secure Institutional equality of Constituent Peoples. Mostar: IDPI, 2016.

Vukoja, Ivan, and Milan Sitarski. "Constitutional, Legal and Political Algorithm of the Electoral Reform in Bosnia and Herzegovina." Mostariensia - Journal of Social Sciences and Humanities 22, no. 1 (May 2018), 505-523.

Watts, Ronald. "Multinational Federations in Comparative Perspective." In Multinational Federations, edited by Michael Burgess and John Pinder, 225-246. London: Routledge, 2007.

Watts, Ronald. Comparing Federal Systems. Montreal, Kingston: McGill-Queen's University Press, 2008. 